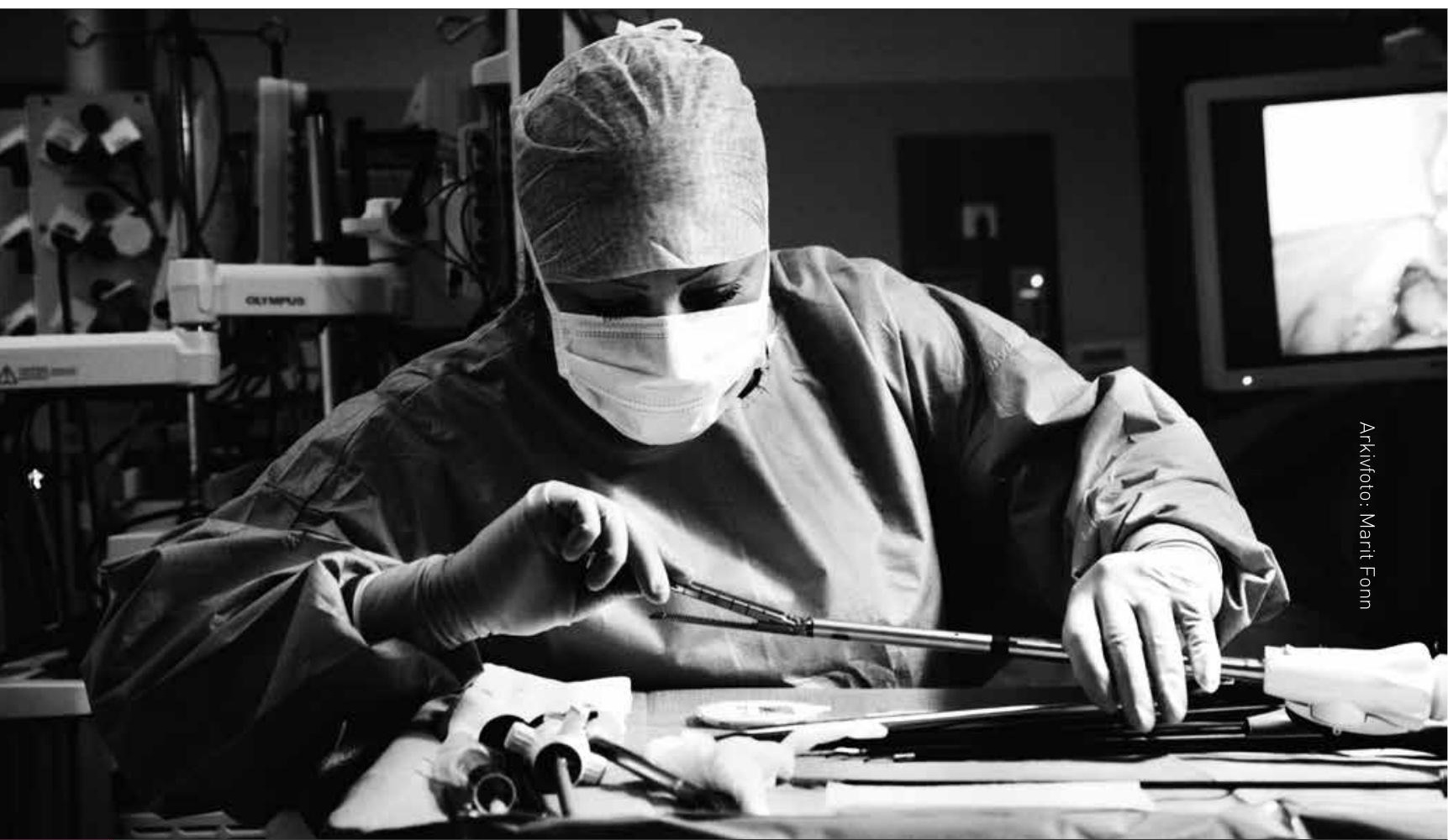

Bakgrunn: Operasjonssykepleiefaget består av flere kunnskapsdimensjoner og litteraturgjennomgang viser at den komplekse kompetansen er lite identifisert og beskrevet.

Hensikt: Hensikten med denne studien var å undersøke operasjonssykepleiernes opplevde kompetanse i forhold til arbeidskrav de møter og sett i forhold til spesifikke kompetanseområder

Metode: En kvantitativ tverrsnittstu- die med et spørreskjema ble anvendt til å kartlegge opplevd kompetanse, perioden våren 2012. Antall respondenter var 30. Databearbeidingen er framstilt med deskriptiv statistikk.

Resultat: Operasjonssykepleierne opplevde godt samsvar mellom opplevd kompetanse og avdelingens arbeidskrav, høyest innenfor teknisk kompetanse, lavest innenfor pårørendekompetanse. Best gjennomsnittlig skår fikk de med 10-14 års erfaring.
Konklusjon: Resultatet viste at operasjonssykepleierne i stor grad opplevde å ha en tilfredsstillende kompetanse i forhold til arbeidskrav. Studien kan bidra til å fokusere på viktige spørsmål knyttet til kompetanseutvikling, også innenfor ikketekniske kompetanseområder. Dette kan gi avdelingen data som kan være med i planleggingen av kompetanseprogram både for den enkelte utøver og for avdelingen som helhet.
Operating theatre nurses experience of competence in relation to the work requirements

Background: The literature shows that the surgical nurses' complicated and complex skills are little identified and described

Objective: The purpose of this study was to investigate the operating theatre nurses' experience of competence in relation to the work requirements and in relation to specific areas of expertise.

Method: To identify perceived compe- tence, a quantitative cross-sectional study using a questionnaire was conducted in the period through 2010 to spring 2012. The participants were a total of 30 respondents. Data processing has been represented with descriptive statistics.

Result: The respondents expressed good correlation between perceived competence and department work requirements - the highest score was obtained in technical expertise, the lowest score in relatives expertise. The best scores were those with 10 to 14 years' experience.
Conclusion: The results show that surgery nurses mostly possess a satisfactory knowledge in relation to the work requirements. The study may help to focus attention on important issues related to human resource development within the non-technical expertise areas also. This can provide the department data that can be included in planning of competence programmes for the department and for the individual practitioner.

Keywords: operation, nurse, skills, quantitative study 


\section{Operasjonssykepleierens vurdering av egen kompetanse i forhold til arbeidskrav}

Forfattere: Astrid Wevling, Thor-David Halstensen og Inger Signe Johansson

\section{NøKKELORD}

- Operasjon

- Sykepleier

- Ferdigheter

- Kvantitativ studie.

\section{INTRODUKSJON}

Operasjonssykepleieren utgjør en viktig del av operasjonsteamet. Ivaretakelse av den akutt/kritisk syke operasjonspasienten krever komplekse kombinasjoner av kunnskap knyttet til ulike kompetanseområder. I tillegg kreves det omfattende kunnskap om operasjonstekniske prinsipper og kirurgisk behandling (1).

\section{KOMPETANSEVURDERING}

Lai (2) skriver at kompetanse er de samlete kunnskaper, ferdigheter, evner og holdninger som gjør det mulig for en person å utføre aktuelle funksjoner og oppgaver i tråd med definerte krav og mål. Sykepleiernes faglige kompetanse beskrives av WHO (3) som et rammeverk av ferdigheter som gjenspeiler kunnskaper og holdninger, inkludert psykososiale og psykomotoriske elementer. Kompetanse omtales som en kombinasjon av kunnskap, skikkethet, vurderinger og holdninger (4), men det foreligger ikke noen klar konsensus om innholdet i begrepet kompetanse innen sykepleie (5).

Profesjonsutøvelsen innen operasjonssykepleie har endret seg over tid. Nyere studier viser økt fokusering på fagets bredde og kompleksitet, både innenfor de tekniske (6-10) og de ikke-tekniske ferdighetene (6,9-18). Tekniske ferdigheter har vært knyttet til praktisk og situasjonsbestemt kunnskap (7-9), samt kunnskap om prosedyrer og standarder som tilpasning, kontroll og bruk av utstyr $(8,10)$. Ikke-tekniske ferdigheter innbefatter samarbeid $(9,14,18)$, kommunikasjon og teamarbeid $(15,16)$, samt helhetlig og empatisk omsorg $(6,9,11,13)$. Operasjonssykepleiers omsorg, som det å gi pasienten anerkjennelse, trygghet og opplevelse av velvære i et høyteknologisk miljø, har stor betydning, (17).

Det er økt vektlegging av kompetanse, sikkerhet og kvalitet i samfunnet (19). Sykehusene er avhengig av høy kompetanse hos sine ansatte for å realisere virksomhetens mål knyttet til kvalitet, pasientsikkerhet, pasienttilfredshet og effektiv drift (20). Нøy kompetanse blant operasjons- sykepleierne $(21,22)$ vil være en vesentlig faktor for kvaliteten på tjenestetilbudet. Ansvaret ligger både hos yrkesutøveren (23), og helseforetaket (24). Bruk av kompetansevurderingsverktøy kan være et tiltak for å identifisere kompetansebehov og bidra til å forbedre praksis (25).

Via litteratursøk fant vi to studier relatert til egenvurdering av operasjonssykepleiers kompetanse $(6,10)$. Studiene har bidratt til å

\section{Hva tilfører artikkelen?}

Studien tyder på at operasjonssykepleiere opplever sin egen kompetanse i stor grad som tilfredsstillende i forhold til kompetansekravene de møter.

\section{Mer om forfatterne:}

Astrid Wevling er operasjonssykepleier og MD. Hun er ansatt som høyskolelektor ved Høgskolen i Østfold og som operasjonssykepleier og studentkoordinator ved Sykehuset Østfold. ThorDavid Halstensen er anestesisykepleier og MD. Han er ansatt som høyskolelektor ved $\mathrm{H} \varnothing \mathrm{g}-$ skolen i Østfold og anestesisykepleier ved Sykehuset $\emptyset$ stfold. Inger Signe Johansson er intensivsykepleier og PhD. Hun er professor i sykepleie ved Høgskolen i Gjøvik, seksjon for sykepleie. Kontaktperson: astridwahiof.no. 
utvikle måleverktøy, identifisere ulike kategorier av kompetanse relatert til utøvelse av operasjonssykepleie $(6,10)$, og gjort det enklere å sammenlikne utøveres kompetanse (26). Språket som brukes i ett instrument har potensial til å utgjøre en forskjell i gyldighet og pålitelighet (27), da meningsinnhold og begrepsforstå- mer instrumentelle omsorg, som er inkludert i Valeberg et al. (10) sin kategori omsorg.

Tidligere studier viser at mye av operasjonssykepleiernes kompetanse er kjent. Egenvurdering av deres komplekse kompetanse er derimot lite identifisert og beskrevet i norske studier. Foreliggende studie kan være et viktig

\section{Teknisk kompetanse hadde den hoyeste gjennomsnittsskåren.}

else er nært knyttet til den språklige forståelsen (28). Forståelsen av instrumentets kvalitet og konteksten det skal brukes i er viktig for et pålitelig resultat (27). Ett kortere instrument oppleves ofte mer brukervennlig, men gruppene av spørsmål bør innholdsmessig tilsvare kompetansekategoriene (27).

To aktuelle instrumenter rettet mot operasjonssykepleie, ble vurdert brukt $(6,10)$. Begge instrumentene viste god gyldighet og pålitelighet. De hadde et tilstrekkelig antall spørsmål og kompetansekategorier som favnet kompleksiteten i faget. Styrken til instrumentet utviklet av Valeberg et al. (10), er at det er utviklet i Norge, testet på spesialsykepleiere, inklusive operasjonssykepleiere. Instrumentets kompetansekategorier ble oppfattet som klarere og mer egnet for den konteksten det skulle brukes i, spesielt ble det vurdert som lettere tilgjengelig i forhold til språk (10). Instrumentet til Gillespie et al. (6) var spesifikt utviklet og testet for bruk i perioperativ sammenheng, noe som var positivt. Spørsmålene ble derimot vurdert som uhensiktsmessig detaljerte. I operasjonssykepleiernes kompetansevurdering savnes kategorien valg og improvisasjonskompetanse. Kategorien empati (6) implementerte ikke operasjonssykepleiernes redskap i virksomhetens arbeid med å videreutvikle kompetanse og kvalitetssikre funksjonsdyktighet knyttet til tjenestetilbudet.

Hensikten med denne studien var å undersøke hvordan operasjonssykepleiere opplevde sin egen kompetanse i forhold til de arbeidskrav de møter innenfor spesifikke kompetansekategorier.

\section{METODE}

Studiens design er en kvantitativ tverrsnittsstudie. Et spørreskjema utviklet av Valeberg et. al (10), ble anvendt til å kartlegge operasjonssykepleiernes opplevde kompetanse knyttet til arbeidskrav relatert til spesifikke kompetanseområder.

\section{Instrumentet}

Spørreskjemaet inneholdt 53 spørsmål, organisert i sju kategorier: Omsorgskompetanse, medisinsk kompetanse, teknisk kompetanse, samarbeids- og pårørendekompetanse, samt pedagogisk og fagutviklingskompetanse, og valg og improvisasjonskompetanse (10). Reliabiliteten var testet med en Cronbachs alpha koeffisient $i$ en tidligere studie (10). Den varierte fra 0,81 til 0,94 for de ulike kompetansekategoriene, og 0,97 for hele skjemaet. Cronbachs alpha koeffisient for foreliggende studie varierte fra 0,8 til 0,95 og 0,97 for hele skjemaet.

I vår studie er instrumentet noe endret og tilpasset operasjonssykepleiere. Elleve spørsmål knyttet til bakgrunnsdata for andre spesialistutdanninger og studenter er fjernet. Ett spørsmål innenfor teknisk kompetanse knyttet til kontroll og bruk av instrumenter, og ett spørsmål innenfor medisinsk kompetanse knyttet til bruk av infeksjonsforebyggende kunnskap, er lagt til. Cronbachs alpha koeffisient for medisinsk kompetanse, inkludert nytt spørsmål, var 0,80 og for teknisk kompetanse 0,88 . Totalt inneholder instrumentet 44 spørsmål.

I en tipoengs Likertskala, svarte operasjonssykepleierne på hvilket samsvar de opplevde mellom sin nåværende kompetanse og den kompetansen de opplevde at arbeidet deres krevde. Tallkarakter $1=$ et betydelig gap mellom egen kompetanse og kompetansekrav $\mathrm{i}$ jobben og $10=$ at man mestret kompetansekravene på en fullt ut tilfredsstillende måte. Verdier under 5 indikerte mangelfull kompetanse (29).

En pilotundersøkelse ble utført ved en sammenliknbar operasjonsavdeling og med de samme inklusjonskriterier som i studien. Seks operasjonssykepleiere deltok. Besvarelsen samt tilbakemeldinger fra deltakerne avdekket godt samsvar mellom hvordan spørsmålene ble oppfattet og det studien ønsket å registrere. Pilotstudien medførte ingen endring på skjemaet, og funnene inngår ikke i studiens resultat.

\section{Utvalg og gjennomføring}

Utvalget besto av operasjonssykepleiere ansatt ved et sentralsykehus i Norge, operasjonssykepleierne var ikke seksjonerte i greinspesialiteter. Inklusjonskriterier var ansettelse 
i minimum 50 prosent stilling de siste 2,5 år. Ledere og fagsykepleiere ble ekskludert. Avdelingsleder utarbeidet en liste over respondenter som fylte inklusjonskriteriene, totalt 52 . Informasjon med forespørsel om deltakelse ble sendt ut via operasjonssykepleiernes mail. Spørreskjemaet $(\mathrm{n}=52)$ ble lagt $\mathrm{i}$ operasjonssykepleiernes posthylle, påført et nummer kun postsekretær hadde tilgang til. Besvarelsen ble levert i en lukket kodet konvolutt til postsekretær. Dette gjorde det mulig å purre opp besvarelser, som ble gjort to ganger. Totalt kom det inn 30 spørreskjemaer, en svarprosent på 59 prosent.

\section{Dataanalyse}

Datamaterialet ble analysert ved hjelp av statistikkprogrammet Minitab versjon 16 (www.minitab.com). Deskriptiv analyse ble gjennomført for beregning av frekvens, prosent, spredning, middelverdi og standardavvik. Dette for å presentere operasjonssykepleiers bakgrunnsvariabler og opplevde egenkompetanse knyttet til arbeidskrav innenfor spørreskjemaets ulike kompetansekategorier. Cronbachs alpha koeffisient ble anvendt for å måle skalaens reliabilitet og interne konsistens.

\section{Etiske vurderinger}

Prinsippene for forskningsetikk er fulgt, i henhold til etiske retningslinjer for sykepleieforskning i Norden. Studien ble i forkant godkjent av Norsk samfunnsvitenskapelige datatjeneste (NSD). Det ble innhentet godkjenning fra helseforetaket. Respondentene fikk informasjon om studiens hensikt og om ivaretakelse av anonymitet $\mathrm{i}$ brevs form. Besvarelse av spørreskjemaet ble regnet som samtykke til å delta.

\section{RESULTATER}

Resultatene fra respondentenes bakgrunnsdata er framstilt i

Tabell 1: Tabell 1: Operasjonssykepleiernes bakgrunnsdata data $(\mathrm{N}=30)$

$\mathrm{N},(\%) \quad \begin{aligned} & \text { Middelverdi } \quad \text { Spredning } \\ & \text { (SD) }\end{aligned}$

Kjønn (n=28)

Mann

Kvinne

25 (89)

Alder $(n=27)$

$49,8(5,7)$

40-59

Antall års erfaring

før spesialutdanning

Erfaring som

operasjonssyke-

pleier $(n=27)$

2-4 år

$8,4(5,7)$

$0-20$

5-9 år

$4(13)$

10-14 år

8 (27)

15-19 år

$6(20)$

20-35 å

4 (13)

5 (17)

tabell 1 og viser fordelingen mellom kjønn, arbeidserfaring og alder hos respondentene. Tabellen viser at operasjonssykepleierne har en høy gjennomsnittsalder. De fleste har lang erfaring som sykepleiere og operasjonssykepleiere, og majoriteten er kvinner.

Tabell 2 viser operasjonssykepleiernes opplevde kompetanse relatert til arbeidskrav. I hvert spørsmål svarer de på hvilket samsvar de opplever mellom sin

petanse. Operasjonssykepleierne skårer høyest på teknisk kompetanse og nest høyest på samarbeidskompetanse og medisinsk kompetanse. De laveste skårene er på pårørendekompetanse hvor også standardavviket viser den største spredningen. Seks enkeltspørsmål har en middelverdi på over 9, alle innenfor teknisk-, medisinsk- eller samarbeidskompetanse. Spørsmålet Evne til å bruke infeksjonsforebyggende

\section{Operasjonssykepleierne opplever selv at de har god omsorgskompetanse.}

nåværende kompetanse innen de ulike kompetansekategoriene, og den kompetansen de opplever at arbeidet krever.

Resultatet i tabell 2 viser at operasjonssykepleiernes vurdering av egen kompetanse $i$ forhold til arbeidskrav er høy. Alle kategoriene har middelverdier på over 8 , unntatt pårørendekom- kunnskap i sykepleiefaglige vurderinger har den høyeste middelverdien. Mer enn halvparten har vurdert sin kompetanse til 10 (framkommer ikke i tabell). Spørsmålet Evne til å benytte pårorende som en ressurs $i$ arbeidet har den laveste middelverdien med en verdi på 7,2. Også innen kategorien omsorg 
Tabell 2: Operasjonssykepleierens opplevde kompetanse relatert til ulike kompetansekategorier

Spørsmålet er som følger: Hvilket samsvar opplever du mellom din nåværende kompetanse og den kompetanse som kreves i jobben (jobbkrav)?

Middelverd SD

\section{Totalt OMSORGSKOMPETANSE}

1. Forstå pasientens situasjon og opplevelser ved sykdom

2. Ivareta pasientens fysiske behov

3. Ivareta pasientens psykiske, sosiale og åndelige behov

4. Ivareta eller styrke pasientens egne ressurser

5. Planlegge og prioritere pasientens behov for sykepleie

6. Ivareta integritet, selvbestemmelse og rettigheter ${ }^{1}$

7. Reflektere over og begrunne egne handlinger

\section{Totalt MEDISINSK KOMPETANSE}

8. Gjennomføre legemiddelhåndtering

9. Vurdere virkning og bivirkning av medikamenter

10. Gjennomføre forordnet medisinsk behandling ${ }^{1}$

11. Bruke medisinske kunnskaper i sykepleiefaglige vurderinger ${ }^{1}$

12. Forberedt på og forebygge komplikasjoner

13. Vurdere når legen bør tilkalles for hjelp/konsultasjon ${ }^{1}$

14. Ta selvstendige avgjørelser når det er nødvendig

15. Bruke infeksjonsforebyggende. kunnskaper i sykepleiefaglige vurderinger

\section{Totalt TEKNISK KOMPETANSE}

16. Kontrollere og bruke instrumenter på en sikker måte

17. Kontrollere og bruke medisinsk utstyr på en sikker måte

18. Tilpasse bruken av medisinsk utstyr

19. Utføre medisinske/tekniske prosedyrer hygienisk

\section{Totalt SAMARBEIDSKOMPETANSE}

20. Kommunisere og samhandle med pasient

21. Samarbeide med egen yrkesgruppe

22. Samarbeide med andre yrkesgrupper

23. Skille egne og andre yrkesgruppers ansvarsområder

\section{Totalt PEDAGOGISK OG FAGUTVIKLINGS KOMPETANSE}

24. Veilede/undervise studenter, kollegaer og samarbeidspartnere

25. Oppsøke ny kunnskap og holde seg faglig oppdatert

26. Ta medansvar for å videreutvikle eller endre praksis

27. Forvalte avdelingens ressurser hensiktsmessig
$8,5(1,2)$

5-10

$8,5(1,2)$

5-10

$8,8(1,0)$

6-10

$7,9(1,4)$

$5-10$

$7,9(1,3)$

5-10

$8,9(1,0)$

$6-10$

$8,9(1,1)$

6-10

$8,7(1,4)$

5-10

$8,8(1,2) \quad 4-10$

$8,7(1,2)$

5-10

$7,9(1,5)$

4-10

$8,9(1,2)$

5-10

$8,8(0,9)$

7-10

$8,9(1,1)$

5-10

$9,2(0,7)$

8-10

$8,8(1,1)$

6-10

$9,3(1,0)$

6-10

$9,0(0,9)$

6-10

$9,1(0,8)$

8-10

$8,7(0,9)$

$6-10$

$8,8(0,9)$

$6-10$

$9,2(0,9)$

7-10

$8,9(0,9)$

5-10

$8,7(1,1)$

5-10

$9,0(0,9)$

6-10

$8,9(0,9)$

7-10

$9,0(0,9)$

7-10

$8,1(1,1)$

5-10

$8,2(1,2) \quad 5-10$

$8,1(1,2) \quad 5-10$

$8,0(1,2) \quad 5-10$

$8,2(0,9)$

7-10 
Tabell 2 fortsetter her:

\begin{tabular}{lll}
\hline $\begin{array}{l}\text { Spørsmålet er som følger: Hvilket samsvar opplever du mellom din nåværende kompe- } \\
\text { tanse og den kompetanse som kreves i jobben (jobbkrav)? }\end{array}$ & $\begin{array}{l}\text { Middelverdi } \\
\text { SD }\end{array}$ & Range \\
Totalt VALG OG IMPROVISASJONSKOMPETANSE & $8,5(1,3)$ & $2-10$ \\
28. Prioritere egne arbeidsoppgaver & $8,2(1,6)$ & $2-10$ \\
29. Forvalte egen og andres kompetanse på en hensiktsmessig måte ${ }^{1}$ & $8,0(1,2)$ & $3-10$ \\
30. Ta selvstendige beslutninger ${ }^{1}$ & $8,5(1,4)$ & $3-10$ \\
31. Ta selvstendig sykepleiefaglig ansvar for pasienten ${ }^{1}$ & $8,8(1,5)$ & $3-10$ \\
32. Prioritere og omprioritere oppgaver raskt ${ }^{1}$ & $8,8(1,2)$ & $5-10$ \\
33. Sette faste rutiner til side og improvisere ${ }^{1}$ & $8,7(1,3)$ & $5-10$ \\
34. Takle uforutsette og kaotiske situasjoner & $8,6(1,1)$ & $5-10$ \\
35. Løse problemer som oppstår & $8,8(1,1)$ & $5-10$ \\
& & $2-10$ \\
Totalt PÅRøRENDE kOMPETANSE & $7,6(1,8)$ & $7,7(2,0)$ \\
36. Takle at pårørende er til stede når du arbeider ${ }^{2}$ & $7,2(1,9)$ & $2-10$ \\
37. Benytte pårørende som en ressurs i arbeidet ${ }^{3}$ & $8,0(1,6)$ & $2-10$ \\
38. Takle sterke følelsesmessige inntrykk og opplevelser & $2-10$
\end{tabular}

${ }^{1}$ Bortfall 1, ${ }^{2}$ Bortfall 2, ${ }^{3}$ Bortfall 3

er det flere lave middelverdier relatert til spørsmålene evne til å ivareta psykiske, sosiale og andelige behov hos pasienten (verdi 7,9), og Evne til à ivareta eller styrke pasientens egenressurser (verdi 7,9). Verdier under 5 som indikerer mangelfull kompetanse (fremkommer ikke av tabell) finnes under pårørendekompetanse med 5 items (5,9 prosent), under valg og improvisasjonskompetanse med 4 items (1,7 prosent) og under medisinsk kompetanse 1 items ( 0,4 prosent).

Figur 1 framstiller operasjonssykepleiernes vurdering av kompetanse knyttet til de ulike kompetanseområdene og relatert til antall års erfaring.

Figur 1 viser at samlet for alle kompetansekategoriene foreligger det en stigning $\mathrm{i}$ egenvurdert kompetanse fram til 10-14 års erfaring. Deretter vises en liten reduksjon i egenvurdert kompetanse fram mot 19 års erfaring, for så igjen å stige noe.

\section{DISKUSJON}

Operasjonssykepleierne opplever godt samsvar mellom opplevd egenkompetanse og opplevelse av arbeidskrav. Opplevd kompetanse relatert til erfaring som operasjonssy-
(34) at kompetanse viser en rask økning på et tidlig stadium av sykepleierkarrieren og en langsommere økning senere.

Det er naturlig at kompetanseveksten er størst de første årene (34). Nye operasjons-

\section{Pårorendekompetanse har den laveste skåren.}

kepleier økte gradvis fram mot 10-14 års erfaring. Generelt kan opplevelsen av høy kompetanse ha sammenheng med lang erfaring i yrket (30-32) og høy stillingsbrøk. Valeberg et al. (10) viser at spesialsykepleiere under utdannelse har en lavere middelverdi i alle kompetansekategorier sammenliknet med nyutdannete spesialsykepleier. Gillespie et al. (33) viser at erfaring og fulltidsstilling som operasjonssykepleier øker den egenvurderte kompetansen. Til sammenlikning viser Takase sykepleiere har mye å lære og læringsmulighetene er mange, likevel er det mer enn erfaring som påvirker utvikling av kompetanse. Hvordan den enkelte utøver utnytter sitt potensial, samt utøvers ressurser, motivasjon og holdning til læring vil ha betydning (2). Erfarne utøvere vil også inneha en mer helhetlig forståelse for kompleksiteten knyttet til ulike situasjoner, noe som gjør dem bedre skikket til å ta valg, improvisere, og prioritere (30). Dette kommer også fram i figur 1. 
Figur 1: Operasjonssykepleierens opplevde kompetanse relatert til antall års erfaring som operasjonssykepleier ( $N=114)$

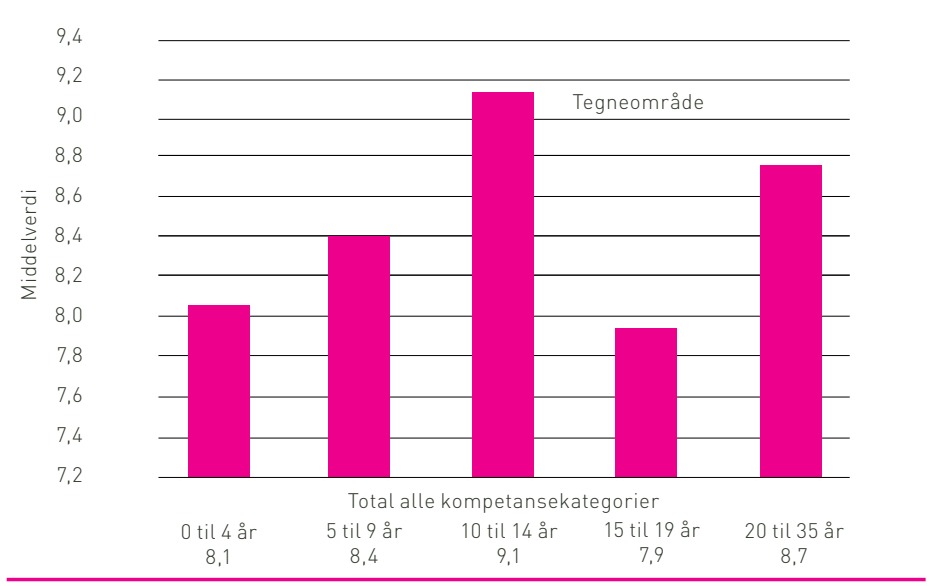

Svaralternativene er gitt i en Likertskala fra 1 - 10.

I vår studie framkommer det att teknisk kompetanse hadde den høyeste gjennomsnittsskåren. Forklaringen kan ligge i sterk fokusering på tekniske ferdigheter, grunnet stadig mer teknisk utstyr på operasjonsavdelingen. Implementering av nytt teknisk utstyr i utøvelsen fører til sterk vektlegging av brukerkompetanse og pasientsikkerhet $(8,35)$. Opplæring i medisinsk-teknisk utstyr er også hjemlet i forskrift (36). Vektlegging av tekniske ferdigheter har en klar sammenheng med økt produktivitet og effektivitet (21, 37). Oppmerksomheten rundt mestring av tekniske ferdigheter kan også henge sammen med at mangelfull kompetanse er svært synlig. Egen erfaring tilsier at tilbakemeldinger fra kirurger ofte er knyttet til mangelfull kompetanse hos operasjonssykepleier, eksempelvis i montering og anvendelse av instrumenter og utstyr.

Medisinsk kompetanse viste også en høy gjennomsnittskår. Bruk av infeksjonsforebyggende kunnskap i sykepleiefaglige vur- deringer hadde den høyeste skåren av alle spørsmål. Mer enn halvparten vurderte sin kompetanse til 10. Et høyt snitt var forventet, relatert til den sterke vektleggingen operasjonssykepleierne har på det infeksjonsforebyggende arbeidet $(1,38)$. På tross av dette er andelen pasienter som får postoperative infeksjoner mellom 3-10 prosent (39) Mange av sårinfeksjonene kan forebygges (38), men årsakssammenhengen er kompleks og relatert til forekomst av ulike risikofaktorer $(39,40)$. Lav middelverdi relatert til spørsmålet Evne til à vurdere virkning og bivirkning av medikamenter kan indikere at spørsmålet ikke ble oppfattet som relevant for operasjonssykepleiere.

Nest høyest middelverdi hadde samarbeidskompetanse og høyest skår var knyttet til å samarbeide med egen og andre yrkesgrupper. Resultatet viser at samarbeid mellom individene $\mathrm{i}$ operasjonsteamet er viktig for å oppnå sikkerhet og kvalitet (41), og god kompetanse er en forutsetning for kvalitet $\mathrm{i}$ planlegging og gjennomføring av arbeidet. Spørsmål relatert til kommunikasjon og samhandling med pasienten skåret noe lavere. Årsaken til dette kan sees i sammenheng med at oppgavefordelingen på operasjonsstua styres av vaner, og en kultur som har utviklet seg over tid (42). Anestesipersonalet har i større grad ivaretatt samtalen med pasienten. Likevel viser en studie (17) at operasjonssykepleierne ønsker å skape tillit og gi pasienten en opplevelse av trygghet og velvære gjennom kommunikasjon og samhandling. Via samtale med pasienten innhentes også kunnskap om pasientens behov og helsetilstand, noe som innvirker på operasjonssykepleiers utøvelse relatert til individuelt tilpasset omsorg, komplikasjonsforebyggelse og sikkerhet $(18,43,44)$.

Operasjonssykepleierne opplever selv at de har god omsorgskompetanse. Deres omsorg er nært knyttet til deres spesifikke kompetanse om operasjonstekniske prinsipper og kirurgisk behandling (45). Omsorg som fenomen er kontekstavhengig, og innvirker på balansen mellom omsorg og teknologi knyttet til tid og oppmerksomhet. Krav som effektivitet, hurtighet, produktivitet og ressursstyring gjør det utfordrende å ivareta alle sider ved omsorgsbegrepet, relatert til de ulike spørsmålene i kategorien. Spørsmål knyttet til den mer instrumentelle siden av omsorg skårer høyt og operasjonssykepleiernes omsorg relateres i stor grad til instrumentelle arbeidsoppgaver $(1,9)$. Omsorg impliserer måten den pasientrettete handlingen utføres på, med vennlighet, respekt og opprettholdelse av verdighet $(13,17)$. Å fà pasienten til å oppleve velvære og trygghet 
er viktig for operasjonssykepleieren (17), men kan være en utfordring da tiden de har til rådighet er knapp (46).

Pedagogisk- og fagutviklingskompetanse har den nest laveste middelverdien. Stadige endringer innen fagområdet gjør det vanskelig å hevde at en til enhver tid er oppdatert. Tilrettelegging for fagutvikling påvirkes av flere ulike faktorer som ikke er direkte knyttet til selve læringen, men avhengig av personalpolitiske, økonomiske og administrative rammer (47). En studie viser at operasjonssykepleiere er positive til forskning, men at de mangler kunnskap om hvordan de skal finne forskningen, samt tid og rom til å lese forskningsartikler (48). Det er en sammenheng mellom hvordan omgivelsene oppmuntrer til å bruke forskning og i hvilken utstrekning forskning anvendes i praksis (48-50).

Kategorien pårørendekompetanse har den laveste skåren, selv om samhandling med pårørende inngår i det ansvaret som påhviler operasjonssykepleierne (1). Valeberg et al. (10) anbefaler i sin studie at kategorien pårørendekompetanse endres ved bruk på operasjonssykepleiere. Det ble ikke gjort i foreliggende studie da spørsmålene ble oppfattet som relevante for pilottestens respondenter. En forklaring kan ligge i at det erfaringsmessig er få operasjoner hvor pårørendes tilstedeværelse er nødvendig. Allikevel spiller pårørende en viktig rolle, blant annet når pasienten er barn, psykisk funksjonshemmete, angstpreget eller demente $(38,51)$. En relevant refleksjon knyttet til den lave skåren, er om operasjonssykepleierne har svart ut ifra en opplevelse av at deres kompetanse ikke anvendes.
En faktor som kan innvirke på opplevd kompetanse er få eller mangelfulle tilbakemeldinger (47). Det kan lede til oppfatningen av at kravene er innfridd. Viktig for operasjonssykepleieren er tilbakemeldinger fra operasjonsteam, ledelse, og samarbeidende avdelinger (postoperativ og sengepost). En realistisk vurdering av egen kompetanse påvirkes av konstruktive og tydelige tilbakemeldinger, men også av nivået på de krav og forventninger som stilles. Tydelig kompetan-

\section{Benyttet kartlegging stiller krav til selvinnsikt og egenvurdering.}

sekrav fra avdelingsledelsen til kvalitetskrav, pasientkrav og samfunnskrav kan innvirke på operasjonssykepleiers egenvurdering av kompetanse. Avdelingens ressurser og operasjonssykepleiernes arbeidsbyrde vil også ha en sammenheng med overskudd, tid og mulighet for kompetanseutvikling $(35,52,53)$.

\section{METODEDISKUSJON}

Ved bruk av kartleggingsinstrumenter for å måle kompetanse, er det viktig at forsker er kjent med instrumentet som anvendes, og hva det kan måle. Resultatets troverdighet henger nøye sammen med riktig bruk av verktøyet (27). En utfordring knyttet til kartleggingsverktøy for kompetansevurdering, er å definere grensen mellom de ulike kompetansekategoriene (27). Ved anvendte instrument ble reliabiliteten evaluert for hver kompetansekategori og for totalskåren. Resultatet viste ingen innbyrdes konflikt, spørsmålene som er stilt er entydige og gir et korrekt bilde i forhold til kategorien de er satt inn i (54). Skjemaet har flere spørsmål innenfor samme kompetansekategori, noe som bidrar til å $ø$ ke validiteten. En fare knyttet til det å endre instrumentet er at skjemaets begrepsvaliditet og pålitelighet endres. En kontroll av korrelasjonen mellom denne studiens to tillagte spørsmål og allerede eksisterende spørsmål i samme kompetansekategori ble utført. På tillagte spørsmål viste både en Pearsons r-test og Cronbachs alpha tilfredsstillende verdier.

\section{Studiens svarprosent var på} 59 prosent, hvilket er noe lavt, men likevel innenfor det som regnes som akseptabelt (54). Likevel vil et begrenset antall respondenter og representasjon fra bare en avdeling svekke validiteten. Overføringsverdien er begrenset. Lignende studier med et større utvalg må til for å avgjøre verdien knyttet til overførbarhet. Spørreskjemaet benytter en Likertskala fra 1 til 10, og gir mange svaralternativer. Skalaen ble beholdt for lettere å kunne sammenlikne funn knyttet til tidligere bruk av skjemaet. En skala med mange svaralternativer stiller krav til respondentenes evne til å vurdere sin kompetanse nyansert, samtidig gir skalaen mulighet til å fange opp flere variasjoner (55).

Resultatet måler kun opplevd kompetanse som er situasjonsavhengig og dynamisk. $\AA$ få uttømmende informasjon via et spørreskjema om operasjonssykepleiernes komplekse kompetanse, og særlig de kontekstuelle nyansene, er utfordrende $(27,56)$. 
Opplevelse av egen kompetanse har sammenheng med evnen til å vurdere kompetanse, og benyttet kartlegging stiller krav til selvinnsikt og egenvurdering. En egenvurdering vil alltid være subjektiv relatert til den enkelte sykepleiers opplevelse av hva god kompetanse er. Likevel er sannsynligheten stor for at respondentenes egenvurdering er nøktern (30). En studie viser at operasjonssykepleierne vurderte sin egen kompetanse lavere enn det både leder og en ekstern tverrfaglig ekspertgruppe vurderte (57). Dette kan gi støtte til at måling av opplevd egenkompetanse som verktøy er troverdig og dermed også resultatene. En annen betraktning knyttet til operasjonssykepleiernes høye vurdering av egen kompetanse, er om respondentene svarer ut ifra hva som forventes av dem (54), samt et behov for å framsnakke faggruppens kompetanse, og slik påvirke resultatet (54).

\section{KONKLUSJON}

Resultatet viste at operasjonssykepleierne i stor grad opplevde å inneha en tilfredsstillende kompetanse. Kategorien teknisk kompetanse hadde den høyeste middelverdien mens kategorien pårørendekompetanse hadde den laveste middelverdien. Mer forskning trengs for å kartlegge operasjonssykepleieres kompetanse, særlig relatert til kategorien pårørendekompetanse. Operasjonssykepleiere med 10-14 års erfaring har den høy- este skåren innen alle kompetansekategorier, sammenhengen mellom erfaring og kompetanse vises også i andre sammenliknbare studier.

Studien kan være et bidrag i arbeidet med å kartlegge operasjonssykepleiernes opplevelse av egen kompetanse. Resultatene kan ha betydning i arbeidet med kompetansekartlegging og kompetanseutvikling, og gir studien legitimitet. Ved å jobbe for en kontinuerlig utvikling og en systematisk oppfølging av kompetansen, vil nivået på tjenestene bli bedre i takt med nye krav og forventninger. Flere studier trengs for å klarlegge operasjonssykepleiernes kompetanse og synliggjøre fagområdets bredde.

\section{REFERANSER}

1. NSFLOS, Norsk sykepleierforbunds landsgruppe av operasjonssykepleiere. Utdyping av operasjonssykepleieres myndighetsområde og funksjonsansvar med funksjonsbeskrivelse Oslo: NSFLOS, Norsk sykepleierforbunds landsgruppe av operasjonssykepleiere; 2008.

2. Lai L. Strategisk Kompetanseledelse. Oslo: Fagbokforlaget; 2013.

3. WHO. Global Standards for the Education of Professional Nurses and Midwives. In: (WHO) WHO, editor. http:// www.who.int/hrh/nursing_midwifery/ en/ 2009 World Health Organization.

4. Cowan DT, Norman I, Coopamah VP. Competence in nursing practice: a controversial concept-a focused review of literature. Nurse education today. 2005;25:355-62.

5. Cowan DT, Jenifer Wilson-Barnett D, Norman IJ, Murrells T. Measuring nursing competence: development of a self-assessment tool for general nurses across Europe. International journal of nursing studies. 2008;45:902-13. 6. Gillespie BM, Polit DF, Hamlin L, Chaboyer W. Developing a model of competence in the operating theatre: psychometric validation of the percei- ved perioperative competence scalerevised. International journal of nursing studies. 2012;49:90-101.

7. Healey AN, Undre S, Vincent CA. Defining the technical skills of teamwork in surgery. Quality \& Safety in Health Care. 2006:15:231-4.

8. Sevdalis N, Undre S, Henry J, Sydney E, Koutantji M, Darzi A, et al. Development, initial reliability and validity testing of an observational tool for assessing technical skills of operating room nurses. International journal of nursing studies. 2009;46:1187-93.

9. Gillespie BM, Chaboyer W, Wallis M, Chang HY, Werder H. Operating theatre nurses> perceptions of competence: a focus group study. J Adv Nurs. 2009;65:1019-28

10. Valeberg BT, Grønseth R, Fagermoen MS. Spesialsykepleieres opplevde kompetanse etter endt utdanning. Sykepleien Forskning. 2009;4:206-13. 11. Mitchell L, Flin R. Non-technical skills of the operating theatre scrub nurse: literature review. J Adv Nurs. 2008;63:15-24.

12. Mitchell L, Flin R, Yule S, Mitchell J, Coutts K, Youngson G. Evaluation of the Scrub Practitioners> List of Intraoperative Non-Technical Skills system.
International journal of nursing studies 2012;49:201-11.

13. Bull R, Fitzgerald M. Nursing in a technological environment: nursing care in the operating room. International journal of nursing practice. 2006;12:3-7.

14. Kondrat BK. Operating room nurse managers-competence and beyond. AORN journal. 2001;73:9-24, 26-7 passim.

15. Lingard L, Espin S, Rubin B, Whyte S, Colmenares M, Baker GR, et al. Getting teams to talk: development and pilot implementation of a checklist to promote interprofessional communication in the OR. Quality \& safety in health care. 2005;14:340-6.

16. Nestel D, Kidd J. Nurses> perceptions and experiences of communication in the operating theatre: a focus group interview. BMC nursing. 2006:5:1. 17. Kelvered M, Ohlen J, Gustafsson BA. Operating theatre nurses> experience of patient-related, intraoperative nursing care. Scandinavian journal of caring sciences. 2012 Sep;26(3):449-57. PubMed PMID: 22077815.

18. Rydenfalt C, Johansson G, Larsson PA, Akerman K, Odenrick P. Social structures in the operating theatre: how 
contradicting rationalities and trust affect work. J Adv Nurs. 2012;68:78395

19. Norge K. Lange linjer - kunnskap gir muligheter. Oslo: Departementenes servicesenter, Informasjonsforvaltning; 2013. 168 s. p.

20. McKinsey \& Company. Investeringer i spesialisthelsetjenesten i Norge. Oslo: McKinsey \& Company; 2011.

21. Gillespie BM, Chaboyer W, Wallis M, Werder H. Education and experience make a difference: results of a predictor study. AORN journal. 2011;94:78-90. PubMed PMID: 21722773

22. Gillespie BM, Chaboyer W, Fairweather N. Factors that influence the expected length of operation: results of a prospective study. BMJ Qual Saf. 2012;21:3-12.

23. Helsepersonelloven: lov av 2 juli 199 nr. 64 om helseperson: Fagbokforlaget Vigmostad og Bjørke; 2014.

24. Spesialisthelsetjenesteloven: Iov 2 juli 1999 nr. 61 om spesialisthelsetjenesten m.m.; sist endret ved lov 4 mai 2012 nr. 23. Bergen: Fagbokforlaget; 2012.

25. Gillespie BM, Chaboyer W, Wallis M. The influence of personal characteristics on the resilience of operating room nurses: a predictor study. International journal of nursing studies. 2009;46:968-76.

26. Gillespie BM, Chaboyer W, Lingard S, Ball S. Perioperative nurses> perceptions of competence: implications for migration. ORNAC journal. 2012;30:17-8, 20-2, 4 passim.

27. Wilkinson CA. Competency assessment tools for registered nurses: an integrative review. Journal of continuing education in nursing. 2013;44:31-7. 28. Føllesdal D, Walløe L. Argumentasjonsteori, språk og vitenskapsfilosofi. Oslo: Universitetsforlaget; 2002. 304 s.:ill.p.

29. Havn V, Vedi C. På dypt vann: om nyutdannete sykepleieres kompetanse i møtet med en somatisk sengepost. Trondheim: Sintef IFIM; 1997. IV, 89 s. : diagr. p.

30. Benner P. Fra novice til ekspert. København: Munksgaard; 1995.

31. Numminen 0, Meretoja R, Isoaho $H$, Leino-Kilpi H. Professional competence of practising nurses. Journal of clinical nursing. 2013;22:1411-23.

32. Meretoja R, Numminen 0 , Isoaho $H$, Leino-Kilpi H. Nurse competence between three generational nurse cohorts: A cross-sectional study. International journal of nursing practice. $2014 \mathrm{Apr} 1$. 33. Gillespie BP, DF; Hamlin, L \& Chaboyer, W. The Influence of Personal Characteristics on Perioperative Nurses' Perceived Competence: Implications for Workforce Planning. Aust- ralian Journal of Advanced Nursing. 2013:14-25.

34. Takase M. The relationship between the levels of nurses> competence and the length of their clinical experience: a tentative model for nursing competence development. Journal of clinical nursing. 2013 May;22:1400-10.

35. Kane-Urrabazo C. Managementss role in shaping organizational culture. Journal of Nursing Management. 2006;14:188-94.

36. Forskrift om bruk og vedlikehold av elektromedisinsk utstyr. FOR 1999 08-20 nr. 955.

37. Gillespie BM, Chaboyer W, Fairweather N. Factors that influence the expected length of operation: results of a prospective study. BMJ quality \& safety. 2012;21:3-12

38. Rothrock JC, McEwen DR, Alexander EL. Alexanderss care of the patient in surgery. St. Louis, Mo.: Elsevier Mosby; 2015. XX, 1226 s. :ill. p.

39. Norsk overvåkingssystem for antibiotikabruk og helsetjenesteassosierte infeksjoner (NOIS). Folkehelseinstituttet [Internett]. 2013

40. Prevalens av helsetjenesteassosierte infeksjoner og antibiotikabruk i sykehus og rehabiliteringsinstitusjoner. Høsten 2014 [Internett]. 2014.

41. Bohmer AB, Wappler F, Tinschmann $T$, Kindermann P, Rixen D, Bellendir M, et al. The implementation of a perioperative checklist increases patients perioperative safety and staff satisfaction. Acta anaesthesiologica Scandinavica. 2012;56:332-8.

42. Lindwall L, von Post I. Habits in perioperative nursing culture. Nursing ethics. 2008;15:670-81

43. Rudolfsson G, von Post I, Eriksson K. The perioperative dialogue: holistic nursing in practice. Holistic nursing practice. 2007;21:292-8.

44. Rudolfsson G. Being altered by the unexpected: understanding the perioperative patientss experience: a case study. International journal of nursing practice. 2014;20:433-7.

45. Nelson DL. Perioperative nursing and its history. Dissector. 2007;35:1923.

46. Moesmand AM, Kjøllesdal A. A være akutt kritisk syk: om pasientenes og de pårørendes psykososiale reaksjoner og behov. Oslo: Gyldendal Akademisk; 2004

47. Illeris K, Andersen V. Læring arbejdslivet. Frederiksberg: Roskilde universitetsforlag; 2004 . 282 s.:fig. p. 48. Hommelstad J, Ruland CM. Norwegian nurses> perceived barriers and facilitators to research use. AORN journal. 2004;79:621-34.

49. Lapierre E, Ritchey K, Newhouse R. Barriers to research use in the PACU.
Journal of perianesthesia nursing: official journal of the American Society of PeriAnesthesia Nurses / American Society of PeriAnesthesia Nurses. 2004;19:78-83.

50. Meijers JM, Janssen MA, Cummings GG, Wallin L, Estabrooks CA, R YGH. Assessing the relationships between contextual factors and research utilization in nursing: systematic literature review. J Adv Nurs. 2006;55:622-35.

51. Blum EP, Burns SM. Perioperative communication and family members perceived level of anxiety and satisfaction. ORNAC journal. 2013;31:14,6-9,346. passim

52. Hertting A, Nilsson K, Theorell T, Larsson US. Downsizing and reorganization: demands, challenges and ambiguity for registered nurses. Journal of advanced nursing. 2004;45:145-54.

53. Bjork IT, Hansen BS, Samdal GB, Torstad S, Hamilton GA. Evaluation of clinical ladder participation in Norway. J Nurs Scholarsh. 2007;39:88-94.

54. Polit DE, Beck CT. Nursing research. Philadelphia: Lippincott Williams \& Wilkins; 2012.

55. Streiner D, Geddes J. Intention to treat analysis in clinical trials when there are missing data. Evidence-based mental health. 2001;4:70-1

56. Nicholson P, Griffin P, Gillis $S$, Wu M, Dunning T. Measuring nursing competencies in the operating theatre: instrument development and psychometric analysis using Item Response Theory. Nurse education today. 2013;33:1088-93.

57. Meretoja R, Koponen L. A systematic model to compare nurses> optimal and actual competencies in the clinical setting. J Adv Nurs. 2012;68:414-22.

Les kommentaren på side 142 > 